\begin{tabular}{|l|l|l|l|}
\hline Eiszeitalter $u$. Gegenwart & 35 & $\begin{array}{r}89-108 \\
14 \mathrm{fig} ., 2 \mathrm{tab} .\end{array}$ & Hannover 1985 \\
\hline
\end{tabular}

\title{
Fluctuation in Sea-Level and Associated Morphological Response: Examples from Denmark
}

\author{
Christian Christiansen, Jens Tyge M $\phi$ Ller \& J $\phi$ Rgen Nielsen *)
}

Sea level fluctuation, hydrographs, coastal morphology, coastal changes, age (90 years), resedimentation rate, $\mathrm{C} 14$ dating, continued uplift.

Denmark, North Sea, Baltic Sea

A b s t r a c t: Data from tide gauges in Denmark show diverging trends in mean sealevel during the past 90 years. Stations in the northern parts of the country have a falling trend $(-0.39 \mathrm{~mm} / \mathrm{y}$ in Hirtshals) while stations in the southern part of the country have a rising trend $(+1.08 \mathrm{~mm} / \mathrm{y}$ in Fredericia). This regional disparity can be partly explained by isostatic uplift of the northern part of the country. There is also a marked seasonal fluctuation in mean sea-level with low levels in the spring and high levels in the autumn. Examples of the effect of these fluctuations on the coastal morphology are discussed. In one area of continued uplift the discussion is expanded to include postglacial coastal changes.

[Meeresspiegel-Schwankungen und damit verknüpfte morphologische Auswirkungen:

Beispiele aus Dänemark]

$\mathrm{Kurzf}$ assung: Daten von Pegelbeobachtungen in Dänemark zeigen zwei verschiedenartige Tendenzen des jährlichen Mittelwasserstandes im Verlauf der letzten 90 Jahre. Stationen im nördlichen Teil des Landes zeigen eine fallende Tendenz $(-0.39 \mathrm{~mm}$ pro Jahr in Hirtshals), während Stationen im südlichen Teil eine steigende Tendenz $(+1.08 \mathrm{~mm}$ pro Jahr in Fredericia) zeigen. Dieser regionale Unterschied kann zum Teil durch isostatische Landhebung erklärt werden. Es gibt auch eine ausgeprägte saisonale Änderung im Wasserstand: niedriger Wasserstand im Frühjahr und hoher Wasserstand im Herbst. Beispiele von küstengeologischen Konsequenzen dieser Wasserstandvariationen werden besprochen. Die Diskussion befaßt sich auch mit post-glazialen Küstenveränderungen in einem Gebiet, in dem die isostatische Hebung auch noch heute andauert.

\section{Introduction}

In recent years attention has been drawn to the world-wide problem of shoreline erosion (TANNER \& STAPOR 1972; Walton 1978 and Pilkey 1981), suggesting that

*) Addresses of the authors: $\mathrm{CH}$. Christiansen, lektor, lic. scient. Geologisk Institut, Aarhus Universitet. DK -8000 Århus C. - Prof. Dr. J. T. M $\phi L E R$, Geologisk Institut, Aarhus Universitet. DK -8000 Århus C. - J. Nielsen, lektor, cand. scient. Geografisk Institut $\emptyset_{\text {ster }}$ Voldgade $10,1350 \mathrm{~K} \phi$ benhavn $\mathrm{K}$. 
coastal erosion is largely due to a slow eustatic rise in sea-level. EMERY (1980), GORWITZ et al. (1982) and BARNETT (1984) propose that sea-level has risen by $1.2-1.4 \mathrm{~mm} / \mathrm{y}$ in the last 100 years and $2.3-3.0 \mathrm{~mm} / \mathrm{y}$ in the last 40 years. Exceptions from these general trends are found in Alaska, Scandinavia and South East Asia (BARNETT 1984).

BRUUN (1962) suggested that sea-level rise could be responsible for the widespread shoreline erosion. Sea-level changes create disequilibrium, resulting in the seaward movement of eroded beach material. Coastal changes can also be caused by seasonal variations in the wave-climate (ELIOT \& CLARKE 1982), nearshore reorganisation of bedforms (NIELSEN \& NiELSEN 1978), changes in sedimentbudget (BIRD \& CHristiansen 1982) as well as various anthropogenic factors (WALTON 1979, CARTER et al. 1983).

This paper will deal with sea-level variations in Denmark from 1890 to 1984 and give some examples on the associated morphological responses. In one area of continuing isostatic uplift the discussion is expanded to include post glacial coastal changes.

\section{Long-term trends}

\section{Mean sea-level}

Long term tide gauge data are available for 10 Danish sites covering the period from 1890 to 1984 . These raw data have been analysed for the period up to 1968 (THOMSEN \& HANSEN 1976) without regard to oceanographical and meteorological effects

Tab. 1: Long term sea-level variation $(\mathrm{mm} / 100 \mathrm{y})$ at 10 Danish stations. Sea-level rise is positive. ROSSITER's data are corrected for oceanographical and meteorological effects.

The tide gauge at Frederikshavn stands on unsteady ground.

\begin{tabular}{|c|c|c|c|c|}
\hline & $\begin{array}{c}\text { Year } \\
\text { of establ. }\end{array}$ & $\begin{array}{c}\text { Uncorrected } \\
\text { HANSEN \& THOMSEN } \\
(1976)\end{array}$ & $\begin{array}{l}\text { Corrected } \\
\text { Rossiter } \\
(1966)\end{array}$ & $\begin{array}{c}\text { From levelling } \\
\text { ANDERSEN et al. } \\
(1974)\end{array}$ \\
\hline K $\phi$ benhavn & 1889 & 24.7 & 23 & \\
\hline Hornbaek & 1891 & 1.1 & -3 & \\
\hline Kors $\phi r$ & 1890 & 79.8 & -3 & \\
\hline Slipshavn & 1890 & 83.5 & 88 & \\
\hline Fredericia & 1890 & 108.4 & 103 & 105 \\
\hline Aarhus & 1889 & 53.4 & 51 & 53 \\
\hline Frederikshavn & 1893 & $(29.4)$ & $(-81)$ & \\
\hline Hirtshals & 1892 & -39.3 & -4 & 24 \\
\hline Esbjerg & 1890 & 116.6 & 148 & 137 \\
\hline Gedser & 1892 & 101.2 & 104 & \\
\hline
\end{tabular}


(Table 1). Rossiter (1967) analysed the same data for the period up to 1962, taking oceanographical and meteorological effects into consideration (Table 1). ANDERSEN et al. (1974) gave an account of secular land movements in Jylland based on repeated levellings about 1890 and about 1950. The corresponding secular changes in mean sea-level are also shown in Table 1. This shows that there is a regional tendency in secular sealevel movements. The rise is largest in the southern parts of the country (Fredericia $1.08 \mathrm{~mm} / \mathrm{y}$; Gedser $1.01 \mathrm{~mm} / \mathrm{y}$ ). This rise in sea-level decreases in a northerly direction to be superseeded by a fall in the northernmost parts (Hirtshals $-0.39 \mathrm{~mm} / \mathrm{y}$ ). A comparison of the three sets of data in Table 1 suggests that meteorological corrections, as applied by Rossiter (1967), are of greatest significance at Esbjerg and Hirtshals, which are situated by the open sea. Stations in the inner Danish waters are more comparable without regard to corrections. These secular changes in mean sea-level give Denmark an intermediate position between North Germany, where sea-level is rising by approx. $2.5 \mathrm{~mm} / \mathrm{y}$ (ROHDE 1977) and Central Sweden, where sea-level is falling by $2-4 \mathrm{~mm} / \mathrm{y}$ (ROSSITER 1967; ÅsE 1980).

In order to eliminate the influence of the long term tidal Saros cycle the changes in sea-level at four Danish stations have been plotted as 19 year running means (Fig. 1). Each plot starts at 0 in the year the station was established. Besides the regional trends, Fig. 1 also shows general tendencies. Peaks, for example, are synchronous on all curves.

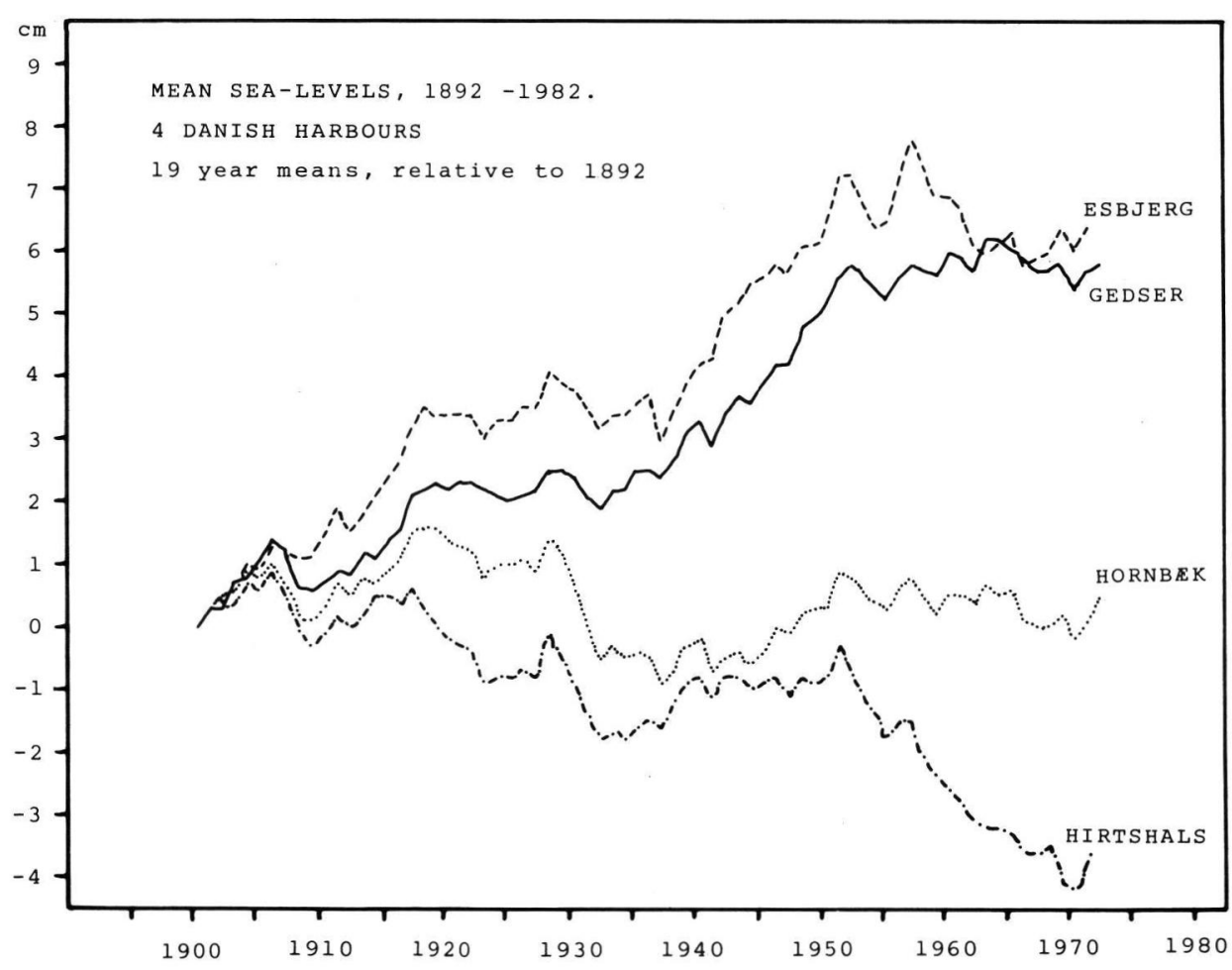

Fig. 1: Changes in mean sea-level since 1892 after the application of 19-year running mean to the raw data. 
Furthermore it is possible to see the difference in trend between the stations on the north sea coast and stations in the inner Danish waters. In recent years both Hirtshals and Esbjerg have had falling trends. The latter is a reversal of the previous tendency. During the same period both Hornbaek and Gedser have remained constant.

\section{Morphological response}

According to BruUn's rule (BruUn 1962; SchwarTZ \& Fisher 1980) one should expect accentuated erosion in the south and diminished erosion or even accretion in the northern parts of Denmark. But it is not as simple as this. Fig. 2 shows that coastal

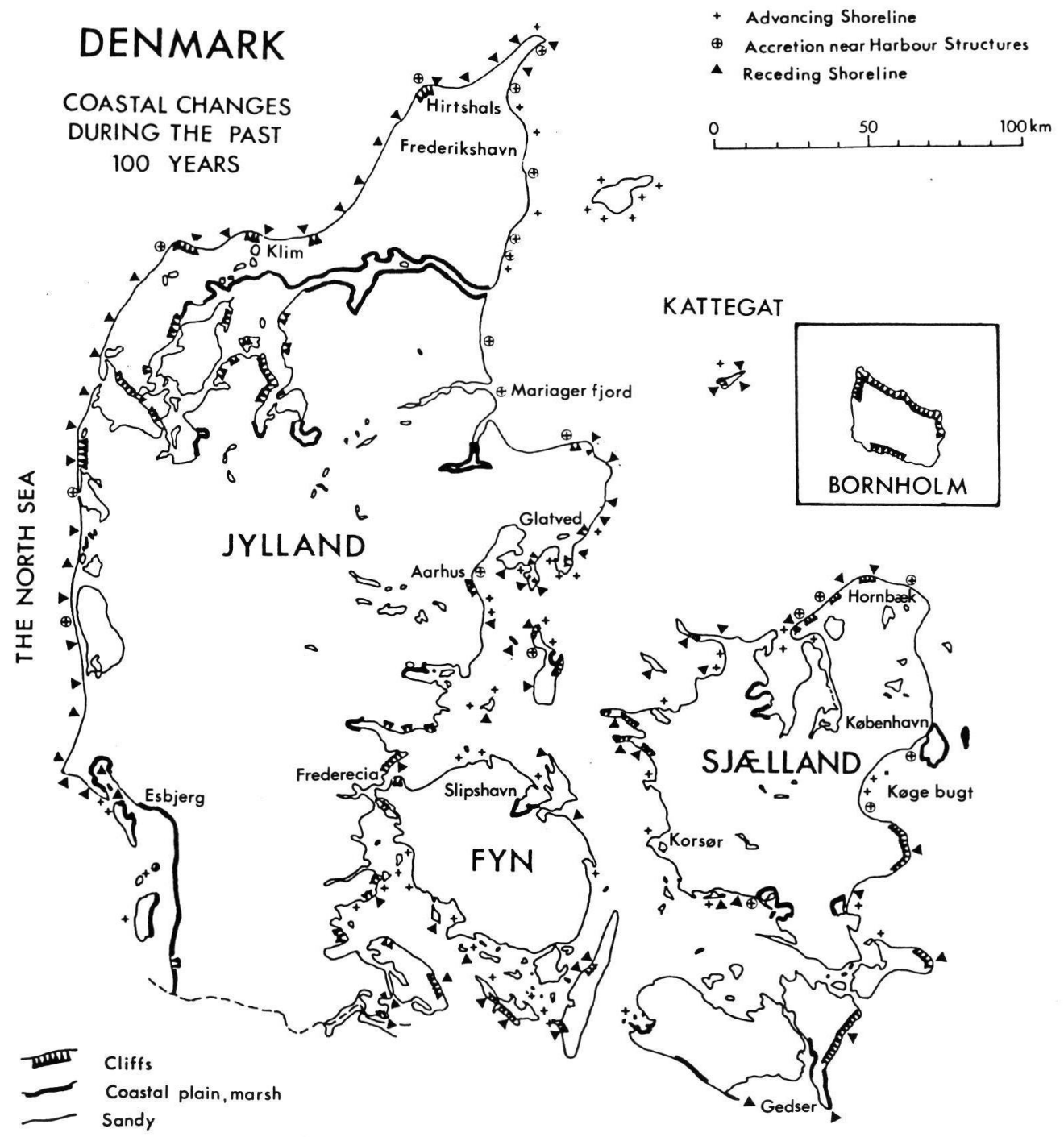

Fig. 2: Location map showing coastal changes in Denmark during the past 100 years. 
recession has exceeded progradation for the past 100 years (some $450 \mathrm{~km}$ of the coast is eroded and some $250 \mathrm{~km}$ is prograded). An assumption for BruUN's rule is that 1) the coast has a fully developed equilibrium profile and 2) there is plenty of loose sediment both on the beach and near-shore. These assumptions are normally fullfilled on coasts with small to moderate gradients, but very seldom on steep coasts. On the other hand, there is a clear difference between coasts facing west and coasts facing east. On the west coasts westerly winds give high sea-level and high waves with resulting erosion. On the east coasts easterly winds give low sea-levels (CHRISTIANSEN 1973) and high waves with resulting lesser erosion. Fig. 3 shows the influence of changes in both water level and sediment budget on coastal morphology. It is possible to have regression even with rising sea-levels if the sediment budget can more than compensate. Thus, the barrier coast in the bay between Blàvand and Sylt in the southwestern part of Jylland, where sea-level is rising $1.17 \mathrm{~mm} / \mathrm{y}$, is prograding. This is due to long-shore sediment transport on the west coast of Jylland from the north towards the south. Apperently, in most parts of the country the morphological responses to long term mean sea-level fluctuations are too small to be distinguished from the results of other coastal processes such as aperiodic storm activity.

An exception can be found in the micro-tidal, low-energy area of Køge Bugt. The bay of Kфge is located south of Copenhagen and is hydrographically part of the Baltic Sea, Fig. 4. The water depths in the bay are shallow (maximum $20 \mathrm{~m}$ ) and the fetches are short, except toward the SE. Mean sea-level is $+12 \mathrm{~cm}$ DNN (DNN $=$ Danish Ordnance Datum) and the tidal range in this part of the Baltic is less than $10 \mathrm{~cm}$.

In the central bay, earlier maps show that a barrier was under formation at least as early as 1860 , but it is first in 1907 that it is shown as chain of islets on the topographical maps. Developments has since then been rapid and already the 1952 map shows a continuous barrier system, at least $7 \mathrm{~km}$ long and only broken by two tidal inlets, Fig. 4 .

To-day the width of the barrier is about $85 \mathrm{~m}$, and it consists of one or two ridges with maximum heights of 1.6-1.9 m DNN. The morphological border between the marine foreland and the beach, the permanent vegetation here mainly Elymus arenaria

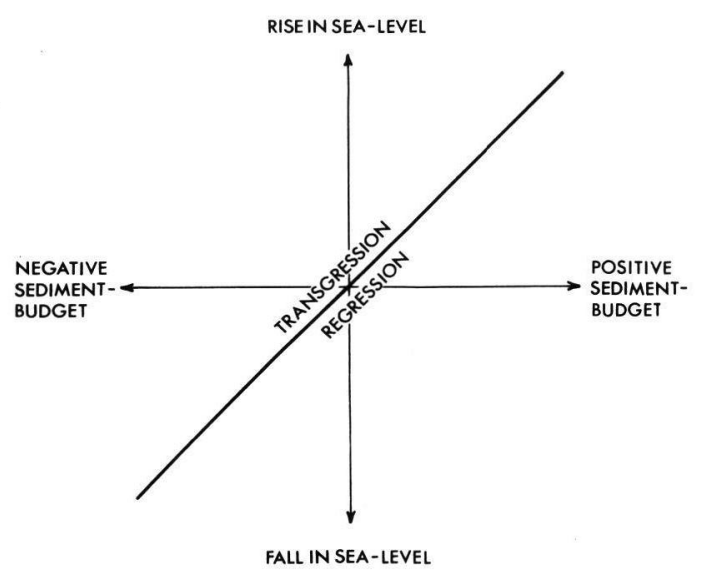

Fig. 3: The influence of changes in sea-level and sediment budget on coastal morphology. 


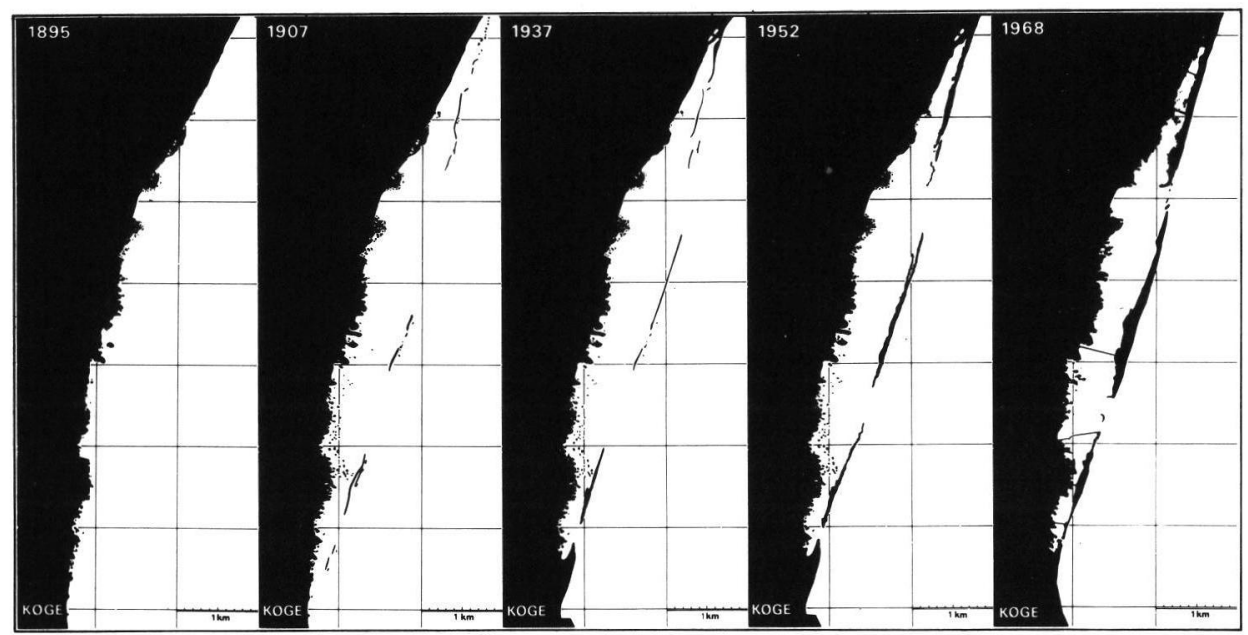

Fig. 4: Development and landward movement of the barrier in Kфge Bugt 1895-1968.

at a level of about $1.3 \mathrm{~m} \mathrm{DNN}$, corresponds to the average of the highest swashes. The upper part of the barrier is covered by small dunes built in the vegetation by windblown sand from the beach.

All levels of a young barrier coast are strongly adjusted to the local dynamics and their variation. Therefore it is interesting that the barrier in Køge Bugt has developed during the last 100 years, a period with transgression (Gedser approx. $1 \mathrm{~mm} / \mathrm{y}$ ). The dominant coastal process has been the development of an equilibrium profile with steeper gradients, i. e. sediment transport toward land. This probably started during the last century with lower sea-levels. This process stopped temporarily due to a lack of mobile sediments in the off-shore zone. Longshore transport of sediments is insignificant in the bay, therefore the total amount of sediment in the barrier and nearshore zone must be considered as constant. The necessary growth of the barrier height, to compensate for increasing water-levels implies a redistribution of the sediments. Map studies show that during development the barrier has moved landward toward a higher part of the profile. This form movement supplies the sediment necessary to build up the top levels of the barrier without changing its horizontal dimensions.

Morphodynamic studies on the barrier coastline (NIELSEN \& NIELSEN 1978) describe the dynamic conditions and morphological results of the landward movement of the barrier. The morphodynamic processes on barrier coasts differ only from other kinds of coastlines during extreme situations, i. e. large waves and high water-levels.

During the night between 21 and 22/11 1971 the wind turned ESE (the direction of the longest fetch) and increased to above $20 \mathrm{~m} / \mathrm{sec}$. At the same time the water-level rose to $124 \mathrm{~cm}$ DNN. The deep water wave height was calculated as about $3.5 \mathrm{~m}$. Extensive parts of the barrier were overwashed due to the combination of wave and water-level. The morphological results was a marked erosion of the beach $(2.8 \mathrm{~m})$ and the exposed part of the dune area $(5 \mathrm{~m})$, and many overwash tongues were deposited behind the barrier ridge, Fig. 5. A study area was measured on 11th and 26th/11 and the volume above $-1 \mathrm{~m}$ DNN was calculated by planimetry. The area stretched $30 \mathrm{~m}$ 


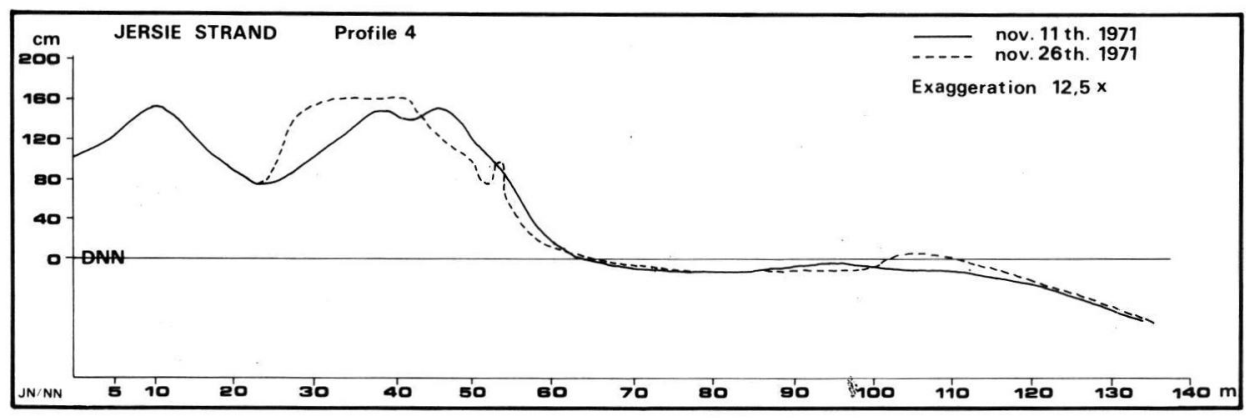

Fig. 5: Cross-section measured on $11 / 11$ and 26/11 1979, i. e. before and after the gale of 22/11. The nearshore zone was apparently not influenced by the gale. Notice the large accumulation of sediment behind the outermost ridge of the barrier.

landwards from the boundry between the beach and the marine foreland. Seawards it stretched $86 \mathrm{~m}$ to the through. The width along the beach was $48 \mathrm{~m}$. The calculation showed, that the volume in the study area was increased by $86 \mathrm{~m}^{3}, 32 \mathrm{~m}^{3}$ of which was found behind the old borderline beach/marine foreland. The overall result was a reinforcement and landward movement of the barrier ridge. The ridge has not been overwashed since November 1971.

At Klim, in the northwestern part of Jylland, coastal changes have been recorded since 1968 by detailed levellings on 18 profiles with a mutual distance of $50 \mathrm{~m}$ (CHRISTIANSEN \& MфLLR 1980). Fig. 6 shows the yearly coastal recession of the $+2.5 \mathrm{~m}$ DNN line together with yearly mean sea-level from Esbjerg (sea-level data from Esbjerg are more complete in these years than the corresponding data from the more closely situated Hirtshals). Fig. 6 shows that there is a clear connection between mean sea-level and mean coastal recession: a departure of $1 \mathrm{~cm}$ of the sea-level from the secular trend corresponds to a recession of $5 \mathrm{~m}$ of the $+2.5 \mathrm{~m}$ level.

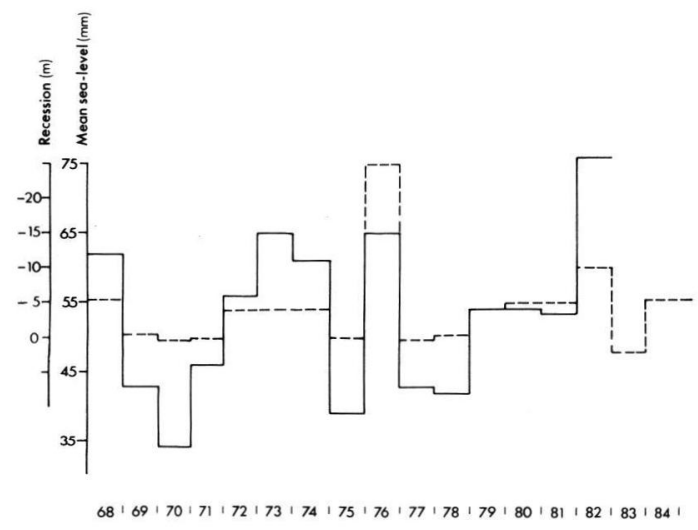

Fig. 6: Yearly mean shoreline movements at Klim compared with yearly mean sea-level at Esbjerg, 1968-1984. 


\section{Seasonal fluctuations}

\section{Sea-level}

Fig. 7 shows the mean seasonal fluctuations of the ten Danish stations. Sea-level is low in the spring and high in the autumn. All stations have low mean level in March, April or May. Stations on the islands have the highest level in August while stations on the east coast of Jylland have a maximum in October. At Esbjerg the highest level is reached in November-December. DiETRICH (1954) showed that the seasonal fluctuation at Esbjerg could be explained by meteorological and oceanographical effects. Wind effects contributed about $66 \%$, water density about $25 \%$ and atmospheric pressure about $10 \%$. Fig. 8 shows the seasonal fluctuations of 24 hour-maximum and -minimum water-levels 1978 from Mosede, Kфge Bugt. Apart from the low level in the spring and high level in the autumn, one can also see, that the diurnal fluctuations in the summer are significantly smaller than in the winter.

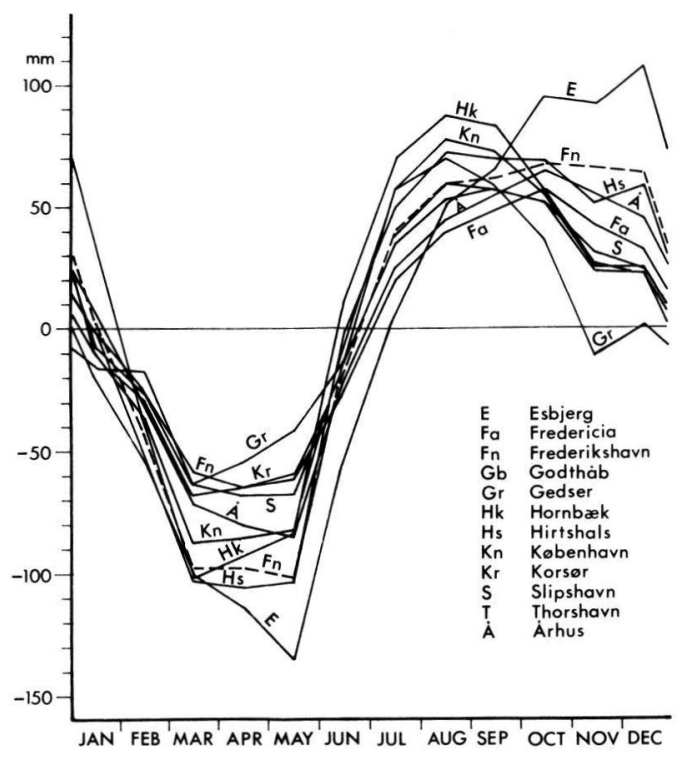

Fig. 7: Monthly mean seasonal fluctuations at ten Danish stations.

Data from Thomsen \& Hansen (1970).

\section{Morphological responses}

An artificial coast has recently been constructed in the northern part of Køge Bugt. Morphodynamic changes in a field area measuring $20 \mathrm{~m}$ (along the beach) by $104 \mathrm{~m}$ were measured from May 1978 to January 1980, only interrupted from January to April 1979 because of sea ice. Seasonal changes on the beach $(0-30 \mathrm{~m})$ and in the nearshore zone $(30-70 \mathrm{~m})$ were recorded (Fig. 9). Apart from the rapid profile and shoreline adjustments of the young artificial coast in 1978 , it is obvious that the morphological 


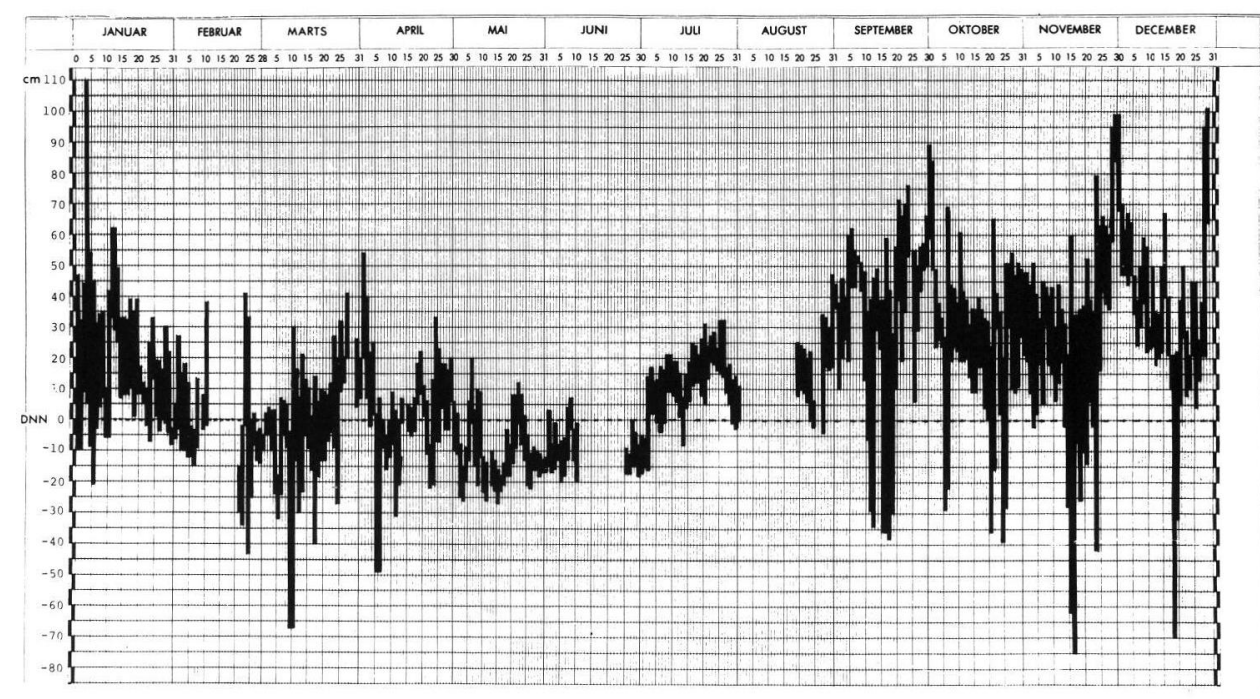

Fig. 8: 24 hour max-min. sea-level 1978 at Mosede, Kфge Bugt.

development during the late spring and summer months is very moderate, due to the low sea-levels and calm weather (Fig. 8). However, there is a tendency to erosion (decreasing volume) of the foreshore and a corresponding accretion in the nearshore.

In the autumn, with prevailing higher sea-levels and a more violent wave climate, the volumetric changes are more distinct. On the foreshore oblique wave directions cause exchange of sediment with adjacent areas, even under situations where the waves are unable to affect the nearshore zone. However, sediment loss occurs in both areas during extreme situations such as in November 1979. Incidentally, during this storm the breakpoint bar was transfered $20 \mathrm{~m}$ seaward and thus out of the study area. The volumetric changes between December 1978 and May 1979 occurred almost entirely during the last days of 1978 . A south-easterly storm with temperatures of $-15^{\circ} \mathrm{C}$ was followed immediately by the freezing of the bay. Consequently, there were no constructive processes after the storm. First during the constructive phase after the storm in November 1979 was there sufficiently wave activity to rebuild the beach and nearshore zone. When the study was ended on January 10,1980, the total volume of the study area was unchanged. The loss in the $0-30 \mathrm{~m}$ area was equal to the accretion in the $70-104 \mathrm{~m}$ area. Before making any conclusions on coastline stability it is thus necessary to make observations over a long period of time to avoid misinterpretating changes which are either seasonal or aperiodic.

Christiansen \& M $\phi$ LLeR (1983) suggested that the seasonal fluctuations in mean sealevel provided good conditions for the establishment of Spartina in Mariager Fjord. Since mean sea-level is low in the spring, in March the micro-tidal flats can have up to 9 days in succession without immersion. The low levels are important, partly because germination is inhibited by salt (HUBBARD 1970) and partly because two or three days without immersion allows the roots to become anchored in the sand. 


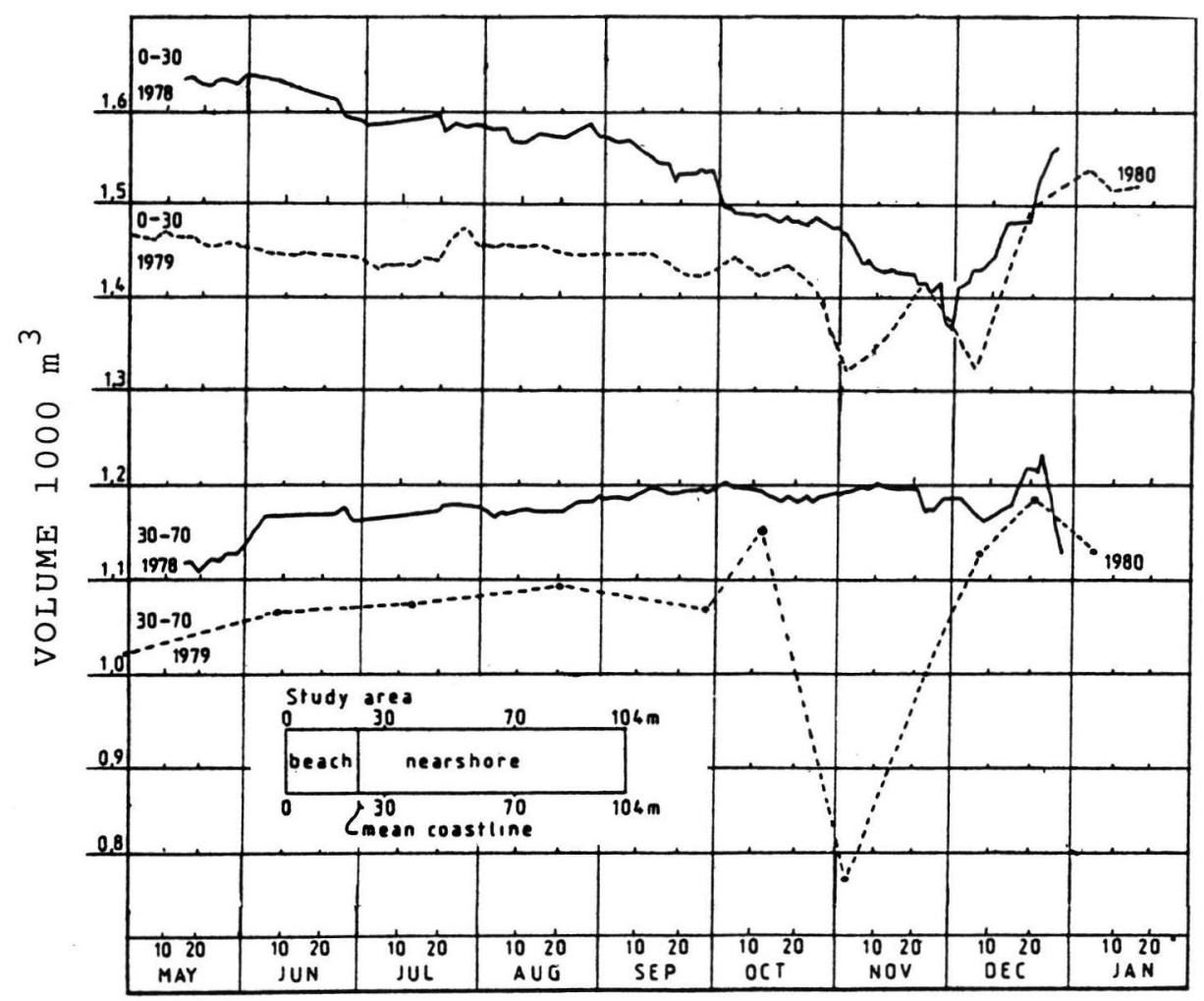

Fig. 9: Volume variations down to $-2 \mathrm{~m} \mathrm{DNN}$ on the beach $(0-30 \mathrm{~m})$ and nearshore (30-70 m), May 1978 to January 1980.

The measurements were interrupted from late December 1978 to late April 1979 because of sea-ice. The study area is $20 \mathrm{~m}$ wide.

Apart from creating new islands, the planting and spread of Spartina resulted, from 1969 to 1978 , in $10 \mathrm{~cm}$ sedimentation with a fining-upward sequence (CHRISTIANSEN \& MILLER 1983). Further, with the changed wave and current conditions caused by Spartina, sediment parameters on the flat have changed. The effect of Spartina diminished with distance. We thus include the changed sedimentation condition under the indirect influence of seasonal fluctuations in mean sea-level.

\section{Aperiodic variations}

\section{Sea-level}

Fig. 10 shows storm water-level variations in Knebel Vig on the east-coast of Jylland. For comparison the predicted tidal variations are also shown. It can be seen that meteorological effects by far surpass tidal variations. On the east-coast of Jylland meteorological induced variations range from $+1.40 \mathrm{~m}$ DNN to $-1.20 \mathrm{~m} \mathrm{DNN}$. The connection between meteorological data and water-level is not immediately clear at first 
sight. Since the sea acts as a 'reversed barometer' a $1 \mathrm{mb}$ pressurefall should cause a $1 \mathrm{~cm}$ rise in sea-level. This effect lies hidden in the effects of the wind. Wind data compared with water-levels shows, that it is regional and not local winds which determine sea-level variations. Further, although the coast faces east, easterly regional winds give low sea level, since they press water out of the Kattegat. Conversely, westerly winds cause inflow and high sea-levels.
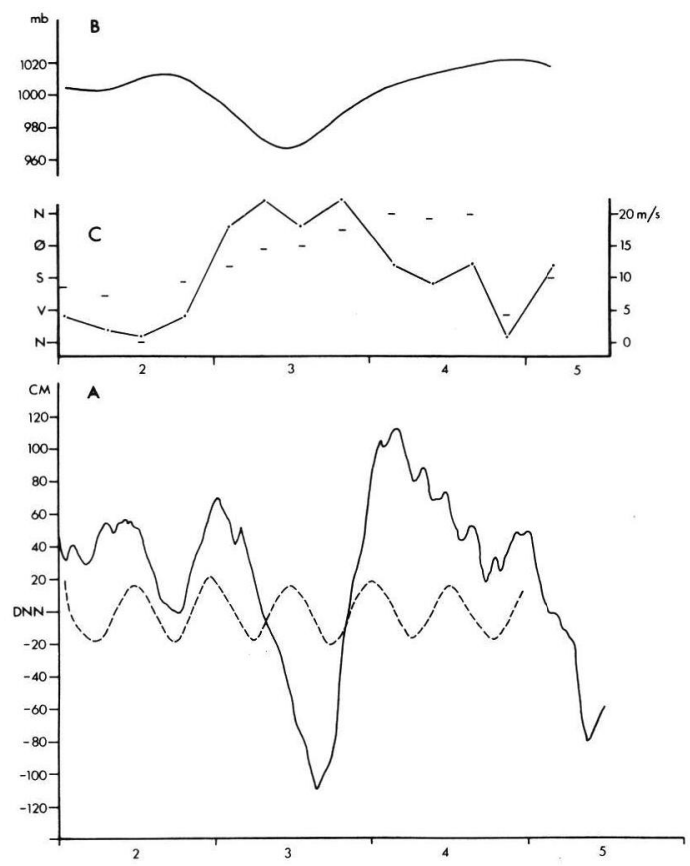

Fig. 10: A) Sea-level observations, Knebel Vig 2-5/1 1976.

The predicted tidal variations are shown by the dot-and-dash curve.

B) Variations in atmospheric pressure.

C) Wind velocity and direction (4 hour means).

The storm surge on the SW coast of Jylland culminated at 14.00 hours on $3^{\text {rd }}$ January ( $+4.91 \mathrm{~m} \mathrm{DNN})$. It culminated at Mariager Fjord at 22.00 hours and at Aarhus the next day at 03.00 hours. Thus the surge travelled down the east-coast of Jylland as a progressive wave with about the same celerity as the tide (CHristiANSEN 1976). Note that on the east coast high onshore wind-velocities prevail when the sea-level is low and the lower offshore wind-velocities prevail when the sea-level is high. Thus, in contrast to the great morphological changes (and flooding) on the west-coast the net effects on the east-coast were small. On the east-coast the highest sea-levels of morphological importance occur during wandering cyclones, when the wind veers $\mathrm{E}$ following a long period of westerly winds. Fig. 10 also shows seiches in the Kattegat with a period of 4 hours during the $4^{\text {th }}$ of January. 


\section{Morphological responses}

BIRD \& Christiansen (1982) shoved that quarry waste dumped on the shore at Glatved in Jylland has been reworked by wave action and formed into a beach ridgeplain. From 1877 to 1976 the coastline extending $5.5 \mathrm{~km}$ north and $4 \mathrm{~km}$ south from the dumping area has prograded up to $220 \mathrm{~m}$. Fig. 11 shows a cross-section through the beach ridge-plain with positions of former shorelines. The crests of recent beach ridges were used by MERTZ (1924) as indicators for highest marine activity to compile the isobase map for post-glacial uplift in Denmark. Fig. 11 shows that, because of aperiodic sea-level changes and waves, this reference level have probably varied up to $1 \mathrm{~m}$ during the last 100 years.

Consequently, it is of importance to know which year a given Tapes/Littorina deposit was related to present sea-level. It is also of importance to remember the influence of slope on wave-swash. A change in slope, for example from $2^{\circ}$ to $5^{\circ}$, increases the swash for the same waves from $0.5 \mathrm{~m}$ to $1.6 \mathrm{~m}$. Further, two wave trains of equal height but with different deep water periods have quite different swashes and thus give different levels of reference for highest marine activity.

Nieisen \& NIELSEN (1978) in their study of a barrier coastline distinguish between the morphological changes due to waves from those due to sea-level variations (Fig. 12). From September $25^{\text {th }}$ to $26^{\text {th }}$ the sea-level increased but there were offshore winds (swell situation). As expected, this produced a weak constructive adjustment of the profile.

During the night of $27 / 9$ the wind veered from $\mathrm{N}$ to $\mathrm{E}$ and at the same time the wind speed increased markedly. At 10.00 hours a destructive profile development was recorded. Between 10.00 and 13.00 this development continues because of increasing wind speed and raised sea-levels, but changes were mainly internal, with very little net change in the area as a whole. At 17.00 the adjustment of the profile was complete, as both wind speed and sea-level remained constant. Until 19.00 the sea-level fell slowly and evenly and wind speed decreased. A constructive profile development has started. This continues during the night until 10.00 on $28 / 9$. Between 10.00 and 14.00 the

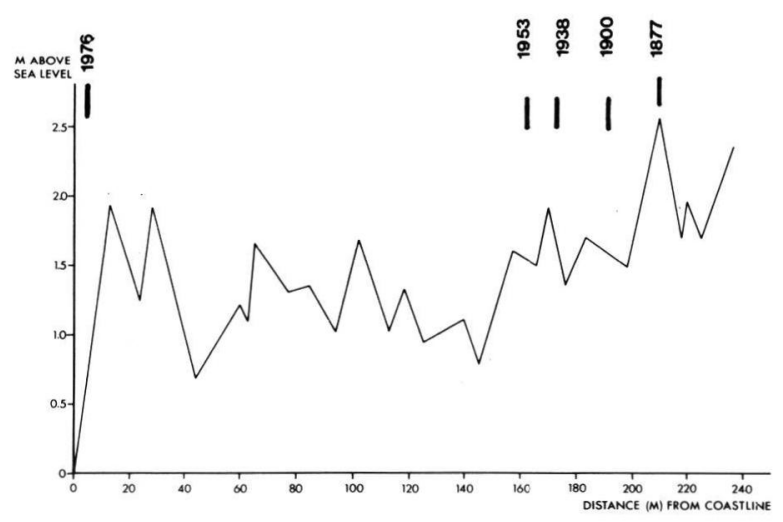

Fig. 11: Topography of the beach ridge plain at Glatved Chalk Quarry.

The ridge field has accumulated since 1877

due to quarry waste dumped on the shore. 


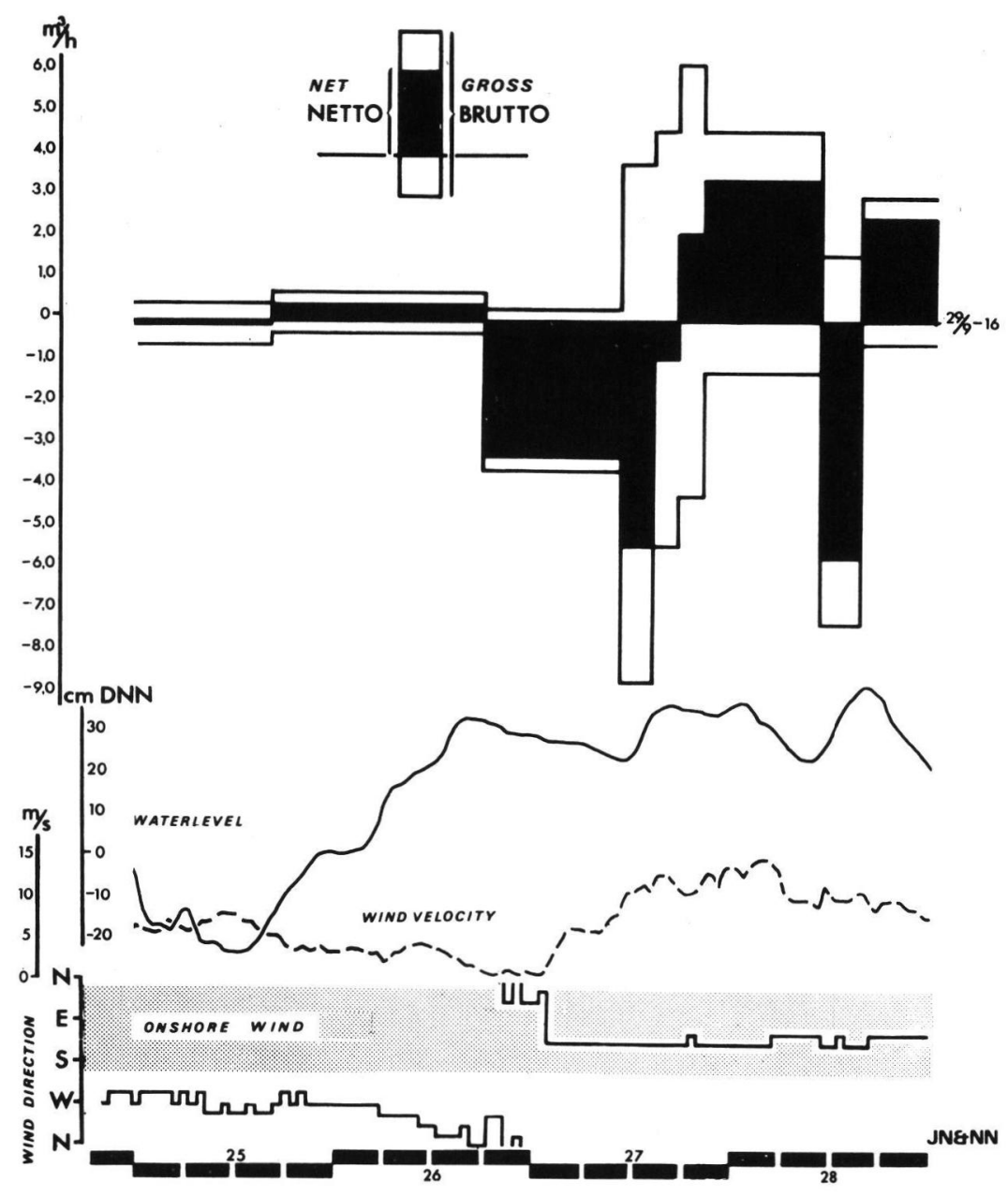

$\begin{array}{llllllllll}S & E & P & T & E & M & B & E & R\end{array}$

Fig. 12: The re-sedimentation rate in $\mathrm{m}^{3} / \mathrm{h}$ for the whole field area $(48 \times 86 \mathrm{~m})$ for the period 25-29/9 1971, together with curves for sea-level, wind velocity and -direction. The white columns in the histogram indicate the gross volume changes.

The difference between the gross and net changes refer to internal morphological developments i. e. nearshore bar migration. The net changes indicate sediment exchange with the surroundings, i. e. general profile adjustments.

sea-level rose significantly, whereas the wind speed remained constant. This results in increased destructive adjustment of the profile, which apperently was at its maximum at the time of measurements. Up to the next measurement at 16.00 both sea-level and wind speed decreased and the final constructive development of the profile was accomplished. There was no net volumetric change in the field area during the period $25-29 / 9$. 


\section{Ancient shorelines}

In the north western part of Jylland sea-level has fallen by up to $27 \mathrm{~m}$ during the last 9000 years (PETERSEN 1981), therefore there are many ancient shorelines and large areas of uplifted sea floor. The origin of the landscape is traditionally ascribed to the Tapes/Littorina sea (2000-4000 B. C.). Yet, some parts of the highest deposits have been dated at 5000 B. C., while younger deposits are dated to 0 B. C. (Petersen 1981). Further in 1978 a medieval ship was found in deposits supposed to date back to the Tapes/Littorina sea (M $\phi$ LLER 1982).

Tab. 2: $\mathrm{C}^{14}$ datings of marine sediments in northern Jylland. For location see Fig. 14

\begin{tabular}{ccrc}
\hline Location & $\begin{array}{l}\text { Level } \\
\mathrm{m} \mathrm{ab} . \mathrm{DNN}\end{array}$ & \multicolumn{1}{c}{$\mathrm{C}^{14}$-dating } & Source \\
\hline 5 & 1.5 & 1160 B.C. \pm 70 & PETERSEN (1981) \\
$\mathrm{C}$ & 0 & 40 A.D. \pm 100 & PETERSEN (1975) \\
13 & 4 & 2040 B.C. \pm 65 & PETERSEN (1975) \\
14 & 3 & 3840 B.C. \pm 105 & PeterSEN (1975) \\
17 & 3 & 5030 B.C. \pm 110 & PETERSEN (1975) \\
\hline
\end{tabular}

The landscape has a substratum of chalk. Many isolated chalk hills occur as small islands in the old sea floors (Fig. 13). In extensive parts of the region the coastal elements are covered by wind-blown sand.

Normally the ancient coastal features are rather difficult to observe in the flat landscape. However, the original topographic survey from the last third of the 19th century is an excellent source for topographic analyses, because the height conditions are described by means of 5 foot $(1.57 \mathrm{~m})$ contours. Owing to the small equidistance quite small coastal elements can be recognized. The boundaries between aeolean and coastal elements are also easy to find. Fig. 13 is a survey, prepared on the basis of the old contour maps of the widespread marine and littoral deposits in the region west of Fjerritslev. The northern part of the area is covered with dunes, which disguise the marine deposits and at the same time protect the old sea floors against the North Sea. In the southern part the surface is mostly below $+4.7 \mathrm{~m}$ DNN. Here the low-lying areas are protected by dikes. Many old inlets, unsuccessfully reclaimed, remain as brackishwater lakes. Fluvio-glacial deposits can be found to the east and west in the region, mostly as thin cover above chalk formations.

The interest for a closer examination of the ancient shorelines and their ages was initiated by the find of the medieval ship (Fig. 14, A) in 1978. The large number of old islands and ridges drew attention to the landscape. Finally, inland place names containing marine and coastal terms indicate the recent presence of the sea. In Denmark place names are rather young, after $800 \mathrm{~A}$. D. However, the existence of place names does not prove that the sea covered the old sea floors that late. 


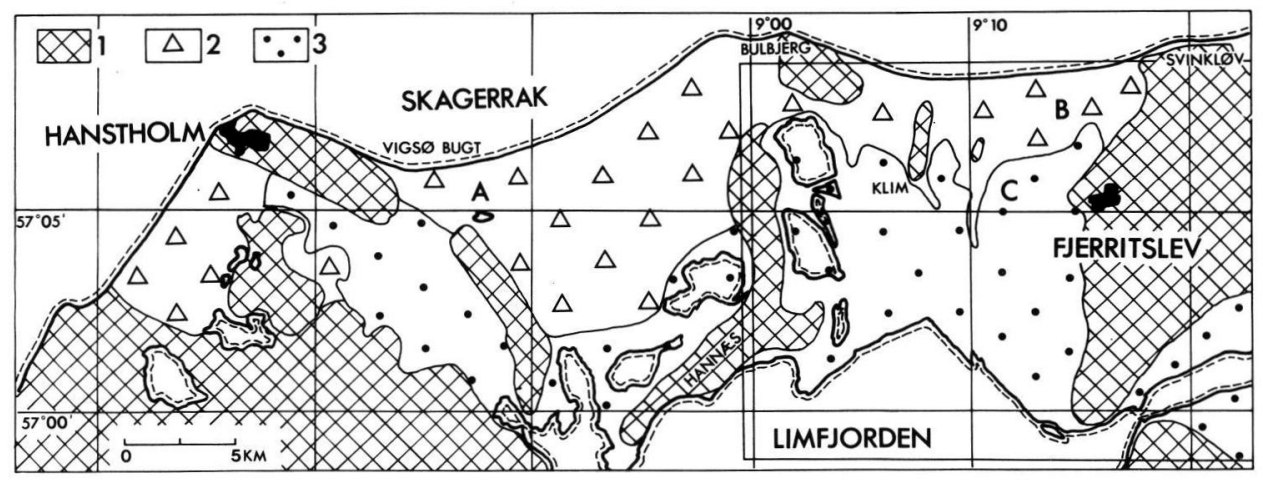

Fig. 13: Characteristic geomorphological features in northwestern Jylland.

1) Glacial and fluvio-glacial deposits.

2) Blown sand overlaying marine deposits.

3) Marine deposits. The shading indicates the spread of Donax vittatus, characterizing the youngest part of the former sea floor. The isolated areas covered with glacial deposits are mostly chalk knolls.

During the uplift, and until the low-lying meadows were protected with dikes, the old sea floors must have been in a state of transition, with many areas dry during easterly winds and flooded during storms from the west. After the dikes were constructed and until pumping stations were built, the meadows could still be flooded with fresh water. However, because of high ground water levels the inhabitants had, and still have, to live on the highest parts of old ridges, islets and curved spits. The place names can hardly have been transferred from nearby active forms, for there are no such forms within $100 \mathrm{~km}$, apart from one curved spit Fig. 14.1) in Limfjorden. If the sea had already retreated when the names were given, then the population must have had a quite unusual knowledge of marine processes and forms in distant regions. The word 'vejle' in the name of the inlet Bygholms Vejle is the Danish word for ford, and the old ford is probably the base for the present highway dam (M $\phi$ LLER 1982). The ford, still in use in the 19th century, is consistent with the existence of a passage between Limfjorden and the North Sea. Because of the fixed banks, the currents in a strait can carry sediments that will settle as soon as the straits opens into the sea, and thus form a bar. Because of the soft sediments in Limfjorden and the great depths in the strait, a bar is the best position for a ford. The stability of the ford mentioned here must be due to sandy deposits, because the depth to the chalk surface is more than $50 \mathrm{~m}$.

Obviously the existence of straits between the North Sea and Limfjorden is closer to historical times than the Stone Age, and datings are highly desirable. The $\mathrm{C}^{14}$ method can normally not be used in a coastal environment because organic matter can only rarely resist the very rough conditions. Fragile deposits such as shells are usually destroyed on a beach ridge under formation, but they can remain behind bars and at the terminal ends of curved spits. Consequently most datings are based on palaeontological methods. However, a geomorphological analysis of the contour maps can lead to a relative dating of the landforms. 


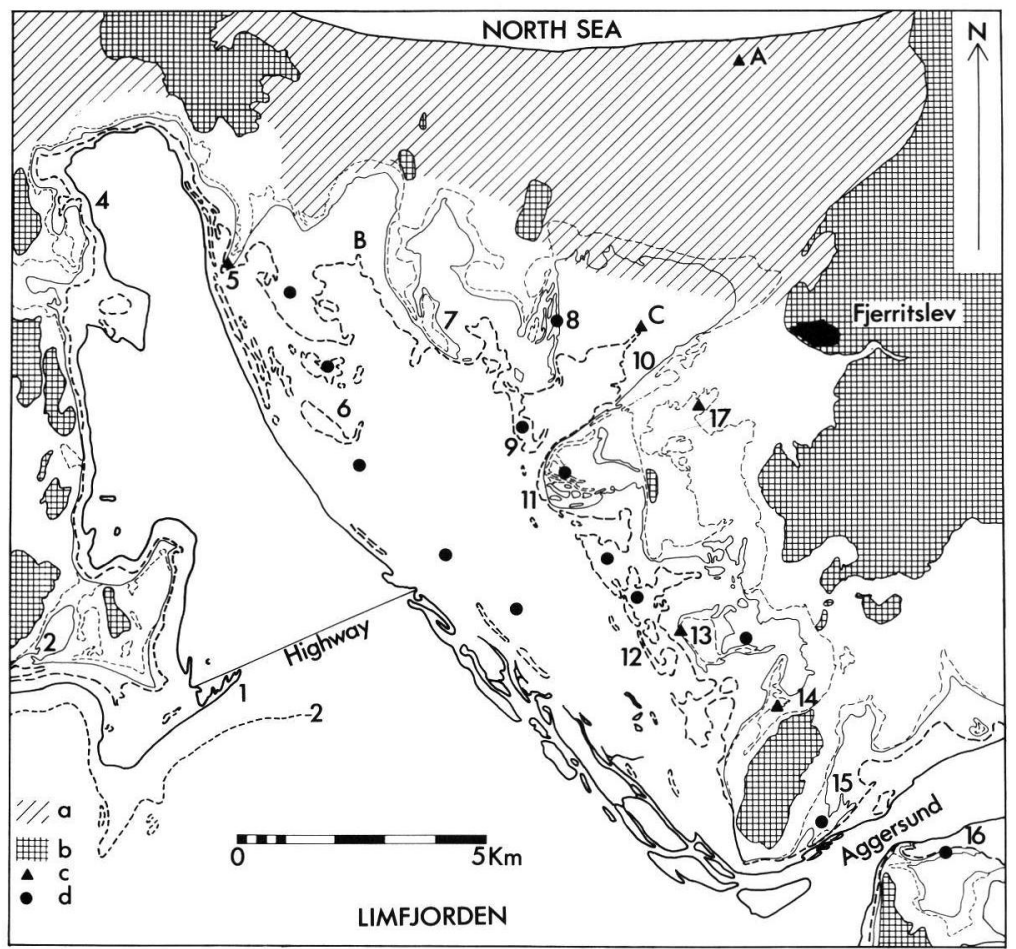

Fig. 14: Ancient coastal elements in a region with uplifted sea floors.

The coastal features appear from the original Danish topographical survey from 1881-1883. The equidistance is 5 Danish feet $(1.57 \mathrm{~m})$. The zero and the 5 feet contour are drawn with thick lines, the lo $\mathrm{ft}(3.1 \mathrm{~m})$ and $15 \mathrm{ft}(4.7 \mathrm{~m})$ contours with thin lines.

a) old sea floor covered with dunes. b) areas above 50 feet $(15.8 \mathrm{~m})$.

c) dated finds. d) place names connected with the sea or the coasts.

The find of the medieval ship has initiated much geological research in the region, in particular with regard to the possible existence of straits. Under the old sea floors there are several depressions in the pre-Quaternary chalk surface (GRY 1979, PETERSEN 1981). Remains of a rather large channel can be found in the infill of a depression close to the old southeastern shoreline (Fig. 14, 11-12). Large parts of this channel could still be seen in 1793 .

In Fig. 14 the contour map has been used to distinguish between two transport directions in the shallow sea under uplift. The predominant wind directions are of great importance, but so is the fetch and the shelter in the shape of hills. At the beginning, when the water was still quite deep so that the North Sea waves could affect the region to a high degree, many coastal elements must have disappeared. Later, as water depth decreased, dunes built by wind blown sand helped to block the North Sea openings further, wind blown sediments helped to decrease water depth in the channels themselves. Ultimately, the straits became so shallow that water flow could only take place at times of extremely high sea level. 
In Fig. 14 the 0 and $+5 \mathrm{ft}(1.6 \mathrm{~m} \mathrm{DNN})$ contours have been drawn with thick lines and the $10 \mathrm{ft}(3.1 \mathrm{~m})$ and $15 \mathrm{ft}(4.7 \mathrm{~m})$ lines are thin. This makes it easier to distinguish the lower and the high marine levels. Areas above $50 \mathrm{ft}(15.8 \mathrm{~m})$ are shaded. The height in which particular coastal features can be found depends on the position. Marine deposits ascribed to the Littorina/Tapes sea can be found at heights from $4.5 \mathrm{~m}$ above DNN at Hanstholm and $8 \mathrm{~m}$ at Fjerritslev (MERTZ 1924).

Two important features can be seen in Fig. 14. The shape of the present shoreline and the $5 \mathrm{ft}$ contour differs markedly from that of the 10 and $15 \mathrm{ft}$ contours. Almost all the coastal elements indicated by the zero and the $5 \mathrm{ft}$ contour can be explained by forces coming mainly from Limfjorden, and thus from the period after the straits were closed. In contrast coastal features indicated by the 10 and $15 \mathrm{ft}$ contours must have been formed by forces coming from both the North Sea and from Limfjorden. These elements are situated at greater heights and the forms are larger than the low-lying elements. The inlet Bygholms Vejle must have been closed before the coastal elements within it were formed, because all the forms can be explained by forces comings from the inlet itself and from Limfjorden.

In Fig. 14 the curved spits 2, 3 and 4 can be explained by local forces and the present fetch in Limfjorden. At 5, 7, 8, 10 and 11 the forces must have come from northern directions. The curved spit at 9 has been formed by forces from the north as well as from the southwest. The system of curved spits at 1 , probably built on a stone reef, is still developing. 12,13 and 14 were formed by forces from Limfjorden. 15 and 16 were influenced by westerly winds, but also influenced by the position on the coasts of Aggersund, a strait with strong currents.

Apart from the relative dating based on topographic evidence there are 5 dated borings which can be used to estimate the age of the two morphological levels. Table 2 shows that the coastal features above $3 \mathrm{~m}$ DNN developed during the Littorina/Tapes period. Features below $3 \mathrm{~m}$ developed much later, some time between $0 \mathrm{~A}$. D. and the first reliable written records from about $1500 \mathrm{~A}$.D. The 11th century ship found well inland from the North Sea coast provides support to this view, but cannot be used as conclusive proof.

\section{Discussion}

Table 1 showed that the mean sea level is rising up to $1 \mathrm{~mm} / \mathrm{y}$ in most parts of Denmark. However, the magnitude of this trend is small compared with short period fluctuations. The variation in annual mean sea levels from one year to another can amount to $130 \mathrm{~mm}$ (ThOMSEN \& HANSEN 1970). Mean monthly variations can amount to $550 \mathrm{~mm}$ while diurnal variations during storm surges can be more than $5000 \mathrm{~mm}$.

It is therefore not surprising that the morphological responses to long term mean sea level fluctuations normally are hidden by short term fluctuations. CARTER (1982) showed that also on the high-energy coasts of Ireland long term fluctuations are disguised. On the other hand $\AA_{S E}$ (1980) reported well preserved responses on the low energy Swedish Baltic coasts with a high ratio of isostatic regression.

Observations from Klim showed that a positive deviation of sea level of $1 \mathrm{~cm}$ corresponds to a $5 \mathrm{~m}$ regression of the $2.5 \mathrm{~m}$ level, thus in line with similar observations in 
Australia. ClaRK \& ELLIOT (1983) showed that beach width responded in an inverse manner to changes in annual mean sea level. A $1 \mathrm{~cm}$ rise corresponded to a $1 \mathrm{~m}$ decrease in beach width. Thus the effect of post-glacial sea level variations are far more complicated than hitherto believed.

The warmer climate in the 20th century is related to a displacement of cyclonic tracks toward higher latitudes (LAMB 1982) and is among other things reflected in increasing sea level. This not only causes extreme wind velocities to be less frequent owing to increased distances to the cyclonic center, but also changes the wind directions. Danish wind statistics for the periods 1876-1925 and 1931-1960 show that the frequency of NW-winds decreased and winds from W and SW are becoming more frequent. Recent work on wind climate (LAMB \& WEISS 1979) shows that the frequency of NW-winds is now again increasing, and so is the number of storms. Especially on coasts facing $\mathrm{W}$ and NW the change in wind direction must result in a variation of the longshore sediment transport and perhaps even change its net direction. On such coastlines heavy erosion or accretion can overshade the effects of the long term sea level variations for many years. The numerous reports of increasing coastal erosion along the North European coastlines during the last decades are perhaps the result of a return of the windclimate to the conditions at the beginning of this century, but now with higher sea levels.

According to morpho-dynamic studies long term morphological consequences of the seasonal variation in the dynamic parameters cannot be seen within the beach and nearshore zone on sandy coasts. However, on the uppermost part of the beach, and especially along the border between beach and marine foreland/hinterland, long term results of aperiodic storms can be seen. This leads to the conclusion that general adjustment of coastal morphology, due to long term variations, does not occur gradually but spasmodically during high energy conditions. On coasts with non-balanced sediment budgets because of longshore transport or recent equilibrium processes, the morphological results of the seasonal variations in the dynamic parameters are more complex.

Systematic sea level recording in Denmark has only been done during the last 90 years. Historical sources are too unreliable to be used directly. On the other hand historical events can be useful for indirect datings. Thus historical sources and finds, such as flooded dwelling sites and high-lying coastal elements and marine fossils, may result in improved interpretations of post-glacial shoreline variations. Such interpretations may also benefit from including the knowledge of responses of more short term sea-level fluctuations.

\section{Acknowledgements}

We thank ConRad Aub-Robinson for improving the English text.

\section{References}

Andersen, O. B., Kejls $\varnothing$, E. \& Remmer, O. (1974): Secular movements within Jutland as determined from repeated precise levellings 1885-94 and 1943-53. - Geodaetisk Instituts Skrifter 3. Rk. XL: 70 pp.; Copenhagen. 
BarnetT, T. P. (1984): The estimation of "Global" sea level change: A problem of uniqueness. — J. Geophys. Res. 89 (C 5): 7980 -7988; Richmond.

BiRd, E. C. F. \& Christiansen, C. (1982): Coastal progradation as a by-product of human activity: an example from Hoed, Denmark. - Geografisk Tidsskrift, 82: 1-4; Copenhagen.

BruUn, P. (1962): Sea level rise as a cause of shore-erosion. - Am. Soc. Civ. Eng. J. Water Har. Div., 88: 117-130; New York.

CARTER, R. W. G. (1982): Recent variations in sea-level on the north and west coasts of Ireland and associated shoreline response. - Proc. R. Ir. Acad., 82 B: 177-187; Dublin.

Carter, B., Lonng, P. \& Shaw, J. (1983): An eighty year history of shoreline erosion in a small Irish bay. - Shore \& Beach, 51, (3): 34-37; Berkeley, California.

Christiansen, C. (1973): Mariager Fjord. - Skrifter i Fysisk Geografi., 5: 79 pp.; University of Aarhus.

- (1976): Forudsigelse af tidevand og andre vandstandsvariationer. - Ph. D. dissertation: 112 pp.; Faculty of Science. Aarhus. - [Unpubl.].

- \& Miller, P. F. (1983): Spartina in Mariager Fjord, Denmark: The effect on sediment parameters. - Earth Surf. Processes and Landf., 8: 55-62; London.

- \& M $\phi_{\text {LleR }}$, J. T. (1980): Beach erosion at Klim, Denmark. A ten-year record. - Coastal Eng., 3: 283-296; Washington.

- \& - (1983): Rate of establishment and seasonal immersion of Spartina in Mariager Fjord, Denmark. - Holartic Ecol., 6: 315-319; Copenhagen.

Clarke, D. J. \& Eliot, I. G. (1983): Mean sea-level and beach-width variation at Scarborough, Western Australia. - Mar. Geol., 51: 251-267; Amsterdam.

Dietrich, C. (1954): Ozeanographisch-meteorologische Einflüsse auf Wasserstandsänderungen des Meeres am Beispiel der Pegelbeobachtungen von Esbjerg. - Küste, 2, 130-156; Heide i. $\mathrm{H}$.

Gorwitz, V., Lebedeff, S. \& Hansen, J. (1982): Global sea level trends in the past century. Science, 215: 1611-1614; London.

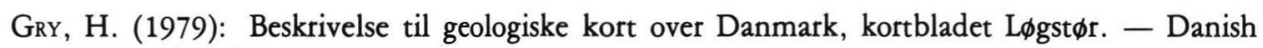
Geological Survey I, 26: 58 pp.; Copenhagen.

HubBard, J. C. E. (1970): Effects of cutting on seed-production in Spartina angelica. - J. Ecol., 58: 329-334; Oxford.

Lamb, H. H. (1982): Climatic changes in our own times and future threats. - Geography, 67, 3: 203-220; Sheffield.

- \& WeIss, I. (1979): On changes of the wind and wave regime of the North Sea and the outlook. - Fachliche Mitteilungen, Amt für Wehrgeophysik Nr. 194: 108 pp.; TrabenTrabach.

Mertz, E. L. (1924): Oversigt over de sen- og postglaciale Niveauforandringer i Danmark. Danish Geol. Surv., II, 41: 49 pp.; Copenhagen.

M $\phi$ LLER, J. T. (1982): Shoreline variations. - GeoSkrifter, 17: 34 pp.; Åthus. 
Nielsen, J. \& Nielsen, N. (1978): Morphology and movements of nearshore sediments in a nontidal environment, Kфge Bugt, Denmark. - Bull. Geol. Soc. Denm., 27, 15-47; Copenhagen.

- \& - (1982): Profiludvikling, sedimentsortering og -omsaetning i relation til den dynamiske påvirkning i den aktive del af kysten, Kфge Bugt. - Rep. Danish Research Council: 57 pp.; Copenhagen. - [Unpubl.].

Petersen, K. S. (1975): Om Limfjordens postglaciale marine udvikling og niveauforhold. Danish Geol. Surv., Yearbook: 28 pp.; Copenhagen.

- (1981): The Holocene marine transgression and its molluscan fauna in the SkagerrakLimfjorden region. Denmark. - Spec. Publ. Int. Ass. Sediment, 5: 497-503; Oxford.

REINECK, H. E. (1967): Layered sediments of tidal flats, beaches and shelf bottoms of the North Sea. - In: Lauff, G. (Ed.) Estuaries. - Am. Assoc. Adv. Sci. pp. 191-206; Washington D.C.

Roнde, H. (1977): Sturmfluthöhen und säkularen Wasserstandanstieg an der deutschen Nordseeküste. - Küste, 30: 52-143; Heide i. H.

Rossiter, J. R. (1967): An analysis of annual sea level variations in European waters. - Geophys. J. R. astr. Soc., 12, 259-299; Oxford.

Schwarts, M. L. \& Fisher, J. J. (1980): Proceedings of the Per Bruun Symposium. - IGU Commission on the coastal environment; Bellingham.

TANneR, W. F. \& Stapor, F. W. (1972): Accelerating crisis in beach erosion. - Int. geogr., 2: 1020-1021; Toronto.

Thomsen, H. \& Hansen, B. (1970): Middelvandstanden og dens aendringer ved de danske kyster. — Det Danske Meteorologiske Institut. Medd. 23: 24 pp; K $\phi$ benhavn.

Walton, T. L. (1978): Coastal erosion - some causes and some consequences. - Mar. Tech. Soc. J., 12: 28-33; Washington.

- (1979): Coastal erosion - some causes and some consequences with special emphasis on the state of Florida. - Shore \& Beach, 47: 7-12; Berkeley, California.

$\AA$ Ås, L.-E. (1980): Shore displacement at Stockholm during the last 1000 years. - Geografiska Annal., 62 A: 83-91; Stockholm. 